Department of Education and Science. Other parts of the public research enterprise are within the purview of a different committee (the Advisory Council for Applied Research and Development), which lately has not surfaced in public view. There is no committee to ask questions about the relationship between civil and military research. It would still need a better secretariat. It could deliver the annual gobbet of advice to the Department of Education and Science more convincingly if it knew more directly what research is being sponsored by other departments. And it could avoid the present frustration by considering how the coordination between the disjoint halves of British public science could lead to greater effectiveness. In the real world, this is the most to hope for but the least for which to clamour.

Third, outrageously, is the remedy suggested in 1982 by the House of Lords: whatever apparatus there may be for giving specialized advice, let there be a minister specialized at receiving it. As things are, the British Government has built itself into a box. Lacking specialists within the civil service (as in West Germany) or an intimate relationship with the government's own specialist agencies (as in France), departments turn to advisory committees for advice which may be taken seriously when it is palatable and otherwise ignored. The downfall of the Advisory Board for the Research Councils can be traced to the occasion last year when it asked for more and was denied. Even if the Prime Minister rather than the Secretary of State was the one who finally said no, the doctrine of collective responsibility lumps the board in with all other dissident disappointed claimants on public funds - local authorities, schoolteachers and the unemployed. There is nobody to put the case, within the government, that the once and for all decline in the quality of the British research enterprise which is now on the cards will cast an even longer shadow. Within the political system to which the British are attached, but which allows ministers to carry only one torch at a time, only the designation of a single-minded political standard-bearer can enable the arguments for rescuing British science to be heard.

\section{Claims to antiquity}

\section{Publishers like to claim either antiquity or modernity. Cambridge can boast of both.}

CAMBRIDGE University Press last week celebrated what it calls its 400th birthday with a "Garden Luncheon Party and Great Exhibition", offering its guests the presence of Prince Philip, the chancellor of the university, some sunshine, a band and a menu from which strawberries, usually mandatory on these occasions, were absent. Cambridge boasts that it is the oldest press in the world with an unbroken history. Only 80 years after Gutenberg, Henry VIII issued Letters Patent in 1534 granting the university "lawful and incontestable power to print there all manner of books". Although the first book did not appear until 1584 - even then, too long an interval to be explained as normal publication delay - it was a single but crucial year ahead of Oxford University Press and three years before the Vatican Press. Confusing for students of priority disputes was a 500-year celebration held by the University of Oxford in 1978. That occasion, Cambridge says, marked the quincentenary of the first book to be printed in the city of Oxford, not by Oxford University Press itself.

In science publishing, Cambridge University Press has been strong in mathematics and physics. In 1713, a revision of Newton's Principia Mathematica appeared under its imprint. Its other authors included James Clerk Maxwell, Rutherford, Jeans, Schrödinger, Einstein and, more recently, Hawking and Chandrasekhar. Undoubtedly the best known of the contemporary works is Joseph Needham's mammoth Science and Civilisation in China, Volume 6, Part 2 of which was published in April. Legally the press is unique, formally a department of the university with the status of a charity. It thus pays no tax. The press is governed by the 18 members of the syndicate, appointed by the university, which must approve all publishing proposals. Mercifully, this apparently anachronistic constitution seems not to be inhibiting.

\section{Unwelcome precision}

\section{Last week's US missile test could destroy}

\section{the $A B M$ treaty.}

STAR wars are becoming uncomfortably realistic. That is one reading of the successful test last week of the US ground-based missile system, based on the Minuteman antiballistic missile, in which a dummy missile warhead was successfully intercepted within hours of a crucial decision by the US Senate about continuing support for these and related projects (see p.660). But last week's test was no part of the comprehensive defence against other people's ballistic missiles that President Reagan has been canvassing this past year. Instead, it is part of what some may call the conventional Anti-Ballistic Missile (ABM) programme which, in the United States and the Soviet Union, has its origins in the early 1960s. The fact that the test (the fourth) succeeded is nevertheless a sign that the treaties which are the fragile reminders of the time, not so long ago, when the superpowers felt able to sign agreements with each other may be coming to the ends of their useful lives.

In 1972, when the ABM treaty was signed between the Soviet Union and the United States, the openly acknowledged incentive was the fear that, without such a treaty, the deterrent value of strategic forces would be eroded. If one power believed that it could destroy the other's missiles, it would be less fearful of making a first strike with its own. That the two powers should thus openly acknowledge the identity of each other's calculations of the psychology of nuclear war was in itself a triumph. The treaty offered a little more - the promise of a respite from ruinously expensive development. But now those benefits appear to be receding. Both sides seem certain to be spurred by last week's test to further development. Technically, there is no reason why the new US system should not be stretched so as to become a second antisatellite (ASAT) weapon, capable of destroying satellites in low orbits, and thus a partner for the US Air Force system called MHV, launched from F-15 aircraft and already tested. (The traditional rivalry between the US Army and the Air Force will, left to itself, ensure rapid progress.) But technically, again, the arguments of the early 1970 s remain valid that no rocket-borne system of this kind can be a certain defence against ballistic missiles with several warheads.

The first casualty will be the ABM treaty. The signatories accepted limitations on the testing of these weapons, although research was to be allowed. The signs now, however, are that unrestrained testing will create the impression, on one side or the other, that the treaty is a dead letter. Then, that is what it will become. And in such a setting, the prospects of an agreement on more elaborate systems to be deployed for longer periods above the atmosphere of the Earth will be even smaller than at present. The United States, after all, has not yet launched as many antisatellite weapons as has the Soviet Union, which began to test its system as long ago as 1968. President Reagan will be able to certify to Congress whenever he likes that he has complied with the Senate's qualification of its grant of star-wars funds by saying that no agreement with the Soviet Union would be "consistent with the national security interests" until the United States has done at least as well. But by then, the Soviet Union will have provided further goals at which to aim.

The depressing reality of all this is that it will be at the least a waste of resources on both sides, and will be dangerous as well. While the star-wars idea is said (by some of those privy to what is planned) to be a technically interesting bag of innovations, nobody has been able to convince the sceptics that a star-wars defensive system could destroy a high proportion of the other side's missiles. And for as long as that remains the case, the course on which the Senate has allowed the US Administration to embark, and on which the Soviet Union is already engaged, cannot counter the objections raised against ABM defence in 1972: if there is a nuclear balance, it is bound to be upset. The irony, of course, is that the two governments were prepared to accept the logic in 1972. They should now follow suit for star wars. 